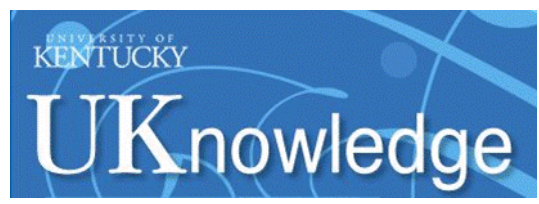

University of Kentucky

UKnowledge

\title{
The derivation of compound ordinal numerals: Implications for morphological theory
}

\author{
Gregory Stump \\ University of Kentucky, gstump@uky.edu
}

Follow this and additional works at: https://uknowledge.uky.edu/lin_facpub

Part of the Linguistics Commons

Right click to open a feedback form in a new tab to let us know how this document benefits you.

\section{Repository Citation}

Stump, Gregory, "The derivation of compound ordinal numerals: Implications for morphological theory" (2010). Linguistics Faculty Publications. 11.

https://uknowledge.uky.edu/lin_facpub/11

This Article is brought to you for free and open access by the Linguistics at UKnowledge. It has been accepted for inclusion in Linguistics Faculty Publications by an authorized administrator of UKnowledge. For more information, please contact UKnowledge@lsv.uky.edu. 
The derivation of compound ordinal numerals: Implications for morphological theory

Digital Object Identifier (DOI)

10.3366/word.2010.0005 


\title{
The derivation of compound ordinal numerals: Implications for morphological theory'
}

\author{
Gregory Stump
}

\begin{abstract}
In the domains of both inflection and derivation, there is evidence for both rules of exponence (which realize specific morphosyntactic properties or derivational categories through the introduction of specific morphological markings) and rules of composition (which determine how such rules of exponence apply in the definition of a compound's inflected forms or derivatives). A single, general rule of composition accounts for the definition of a wide range of derivatives from compound bases; nevertheless, ordinal derivation demonstrates the considerable extent to which rules of composition may vary across languages. Evidence from a diverse range of languages is used to motivate a typology of ordinal derivation whose distinct types embody different rules of composition.
\end{abstract}

\section{Derivational marking in compounds}

The expression of a derivational category $\mathrm{C}$ is customarily equated with the application of a word-formation rule relating a base $\mathrm{B}$ of the appropriate sort to a derivative $\mathrm{D}$, whose form ordinarily differs from that of $B$ in that it contains some formal mark of category $C$; for instance, the expression of the derivational category 'privative adjective' is equated with the application of a rule relating a noun $\mathrm{B}$ to an adjective B-less. (Hereafter, I shall refer to derivational rules of this sort, which introduce specific morphological markings (such as -less) as RULES OF DERIVATIONAL EXPONENCE.) In many cases, the expression of a derivational category $\mathrm{C}$ involves not only a rule $\mathrm{R}$ of derivational exponence, but also an additional rule specifying how $\mathrm{R}$ is involved in the expression of $\mathrm{C}$ when the base is a compound. In instances in which the compound is headed, this additional RULE OF COMPOSITION very often requires the application of $\mathrm{R}$ to the compound's head. That is, for any rule of derivational exponence Deriv, the application

Word Structure 3.2 (2010): 205-233

DOI: $10.3366 / \mathrm{E} 1750124510000590$

(C) Edinburgh University Press www.eupjournals.com/word 
of Deriv to a compound [X Y] headed by $\mathrm{Y}$ is very often determined by the rule of composition in (1):

(1) Rule of composition for $\operatorname{Deriv:} \operatorname{Deriv}([\mathrm{X} Y])=[\mathrm{X} \operatorname{Deriv}(\mathrm{Y})]$

On first consideration, (1) might appear to be the ONLY rule of composition that is ever needed in the derivational domain; my purpose here is to challenge this assumption. In particular, I shall demonstrate that in deriving ordinal numerals from their cardinal counterparts, languages exploit a wide array of rules of composition, including but by no means limited to (1).

I first discuss rules of composition that are widely observable in the domains of inflection and nonordinal derivation (\$2). I then discuss the derivation of ordinal numerals in a range of languages, including the rules of composition that are involved in this derivation (\$3). The evidence that I discuss motivates a richly varied typology of ordinal formation and leads to the conclusion that in the derivational domain, rules of composition may assume a variety of different forms ( $\$ 4)$.

\section{Rules of composition in inflection and in nonordinal derivation}

There is clear evidence for a distinction between rules of exponence and rules of composition both in the derivational domain and in the domain of inflection. Consider first the case of inflection. In the inflection of English, various lexically conditioned rules of inflectional exponence are involved in the definition of past-tense forms such as lived, did, sang, ate, and spent; on the other hand, a single rule of composition guarantees that headed compounds such as OUTLIVE, OVERDO, OUTSING, OVEREAT and OUTSPEND inflect for past tense on their head in the manner required by its lexical conditioning: outlived, overdid, outsang, overate, outspent. Stump (2001: 115) calls this rule of composition THE HEAD-APPLICATION PRINCIPLE and argues that it is a universal of inflectional morphology. According to this principle, the result of applying a rule Infl of inflectional exponence to a compound [X Y] headed by $\mathrm{Y}$ is the compound $[\mathrm{X} \operatorname{Inf}(\mathrm{Y})]$. The only kind of situation in which the Head-Application Principle does not enter into the inflection of a compound [X Y] is one in which the rule defining the compound [X Y] stipulates that $\mathrm{X}$ and $\mathrm{Y}$ are both uninflected stems; in such cases, rules of inflectional exponence must treat [X Y] as an unanalyzed whole (Stump 2001: 114ff).

The rule of composition in (1) in many cases functions as the derivational counterpart of the Head-Application Principle. Thus, consider the formation of denominal occupation nouns in English. Given a noncompound disciplinary noun of the form X, one can represent the form of the corresponding occupational derivative as the result of applying a function OccupDeriv to X. The evaluation of OccupDeriv is lexically conditioned: where $\mathrm{X}=$ physics, $\operatorname{OccupDeriv}(\mathrm{X})=$ physicist (in which -ist supplants the final $s$ in physics and induces velar softening, however this is to be formulated); where $\mathrm{X}=$ economics, OccupDeriv $(\mathrm{X})=$ economist (in which -ist supplants the final $-i c s$ in economics); and where $\mathrm{X}=$ linguistics, $\operatorname{OccupDeriv}(\mathrm{X})=$ linguist (from which the final $-i c s$ in linguistics is simply absent). This lexical conditioning is represented in (2). 
(2) Lexical conditioning in the derivation of denominal occupation nouns in English

\begin{tabular}{|l|c|c|c|}
\hline \multirow{2}{*}{\begin{tabular}{c}
\multirow{2}{*}{ Disciplinary } \\
noun X
\end{tabular}} & \multicolumn{3}{|c|}{ Occupational derivative OccupDeriv $(\mathrm{X})$} \\
\cline { 2 - 4 } & absence of $-\mathrm{s}$ & absence of -ics & absence of -ics \\
addition of -ist & addition of -ist & no addition of -ist \\
\hline physics & physic-ist & & \\
economics & & econom-ist & linguist \\
\hline
\end{tabular}

When the base of derivation is a compound disciplinary noun [X Y], the form of the occupational derivative is in general $[\mathrm{X} \boldsymbol{O} c \boldsymbol{c u p D e r i v}(\mathrm{Y})]$, where $\boldsymbol{O} c c u p D \operatorname{eriv}(\mathrm{Y})$ exhibits the lexical conditioning specifically associated with $\mathrm{Y}$; for instance, the compound disciplinary nouns in (3a) have the occupational derivatives in (3b). This regularity in the formation of the occupational derivatives from compound bases may be attributed to the rule of composition in (1).

(3) Denominal occupation nouns (b) derived from compounds (a)
a. high-energy physics
b. high-energy physicist

home economics

home economist

Romance linguistics Romance linguist

This rule of composition is the cause of the 'bracketing paradoxes' observed by Spencer 1988: logically, atomic scientist has the structure [[atomic science] -ist], yet morphologically, as an effect of (1), it has the realization [atomic [scient-ist]]. Because of (1), it is fallacious to expect a derived lexeme's logical structure to be isomorphic to its morphological realization: the meaning of the lexeme ATOMIC SCIENTIST is related to the meaning of the lexeme ATOMIC SCIENCE, but this relation is not mediated by ATOMIC SCIENTIST's morphological realization as [atomic [scient-ist]].

In the examples in (3), the rule of composition in (1) functions very much like the Head-Application Principle; just as the latter principle causes inflectional markings to be situated on the head of a compound, so (1) causes derivational marking to be situated on the head of each compound in (3a). But unlike the Head-Application Principle, the rule of composition in (1) doesn't invariably define a pattern of head marking. Consider, for instance, the derivation of diminutives from exocentric [V N] compounds in Spanish (Catalán 1995).

Suppose first that given a noncompound Spanish noun $\mathrm{X}$, the form of the corresponding diminutive derivative is the result of applying a function Dimin to X. On that assumption, the evaluation of Dimin must be conditioned both by X's gender and by its prosodic characteristics: where the derivational base $\mathrm{X}$ is masculine, $\operatorname{Dimin}(\mathrm{X})$ is also masculine and exhibits a diminutive marker from column $\mathrm{M}$ of (4); where $\mathrm{X}$ is feminine, $\operatorname{Dimin}(\mathrm{X})$ is also feminine and exhibits a diminutive marker from column F; 
and the choice among the markers in rows $(4 a-c)$ depends on the derivational base's prosodic characteristics, as in (5).

(4) Variant realizations of the Spanish diminutive suffix

$\begin{array}{lll} & \mathrm{M} & \mathrm{F} \\ \text { a. } & -i t o & -i t a \\ \text { b. } & \text {-cito } & \text {-cita } \\ \text { c. } & \text {-ecito } & \text {-ecita }\end{array}$

(5) Prosodic conditioning in the derivation of diminutives in Spanish

\begin{tabular}{|c|c|c|c|c|c|}
\hline \multicolumn{2}{|c|}{ Base } & \multicolumn{3}{|c|}{ Diminutive suffix (masc./fem.) } & \multirow[b]{2}{*}{ Example } \\
\hline $\begin{array}{c}\text { Number } \\
\text { of syllables }\end{array}$ & $\begin{array}{c}\text { Final } \\
\text { syllable }\end{array}$ & -ito/-ita & -cito/-cita & -ecito/-ecita & \\
\hline \multirow[t]{2}{*}{$>2$} & open & $\begin{array}{l}\text { sombrero 'sombrero' } \\
\text { principe 'prince' } \\
\text { campana 'bell' }\end{array}$ & & & $\begin{array}{l}\text { sombrerito } \\
\text { principito } \\
\text { campanita }\end{array}$ \\
\hline & $\begin{array}{l}\text { ends } \\
\text { in } n\end{array}$ & & $\begin{array}{l}\text { corazón 'heart' } \\
\text { canción 'song' }\end{array}$ & & $\begin{array}{l}\text { corazoncito } \\
\text { cancioncita }\end{array}$ \\
\hline \multirow[b]{2}{*}{2} & $\begin{array}{l}\text { ends in } \\
e, r, z\end{array}$ & & $\begin{array}{l}\text { jefe 'head, chief' } \\
\text { pintor 'painter' } \\
\text { nariz 'nose' }\end{array}$ & & $\begin{array}{l}\text { jefecito } \\
\text { pintorcito } \\
\text { naricita }\end{array}$ \\
\hline & other & $\begin{array}{l}\text { mesa 'table' } \\
\text { mano 'hand' } \\
\text { paño 'cloth' } \\
\text { pañal 'diaper' } \\
\text { señal 'sign' }\end{array}$ & & & $\begin{array}{l}\text { mesita } \\
\text { manito } \\
\text { pañito } \\
\text { pañalito } \\
\text { señalita }\end{array}$ \\
\hline 1 & closed & & & $\begin{array}{l}\text { pan 'bread' } \\
\text { cruz 'cross' } \\
\text { mes 'month' }\end{array}$ & $\begin{array}{l}\text { panecito } \\
\text { crucecita } \\
\text { mesecito }\end{array}$ \\
\hline
\end{tabular}


Now, Spanish has a class of exocentric compounds of the form [V N], e.g. lava-platos 'dishwasher' [wash-dishes]. Diminutives derived from such compounds are defined by the rule of composition in (1). The effect of (1) is to cause the realization of diminutive morphology in a diminutive deriving from an exocentric compound to be conditioned not by the prosody of the compound as a whole but by that of the compound's righthand member (minus any plural morphology), as in the examples in (6). These cases are unlike that of high-energy physicist, since in these cases, the derivational marking is not situated on the compound's head; indeed, the compound has no head. Even so, high-energy physicist and quitasolecito are alike in that each derives from a compound $\mathrm{C}$ through the application of the relevant rule of derivational exponence to C's second member (whether or not this is C's head). Should this be seen as evidence that the rule of composition in (1) is a universal principle of derivation?

(6) Exocentric compounds and their diminutives in Spanish

\begin{tabular}{|c|c|c|}
\hline & \\
\hline & Exocentric compound V-N & Diminutive \\
\hline $\mathrm{N}_{2}$ is a closed monosyllable & $\begin{array}{l}\text { quita-sol 'parasol' } \\
\text { traga-luz 'skylight' }\end{array}$ & $\begin{array}{l}\text { quitasolecito } \\
\text { tragalucecitas }\end{array}$ \\
\hline $\begin{array}{l}\text { Minus its plural morphology, } \\
\mathrm{N}_{2} \text { is disyllabic and ends in a } \\
\text { vowel other than } e\end{array}$ & $\begin{array}{l}\text { apaga-velas 'candle snuffer' } \\
\text { par-aguas 'umbrella' } \\
\text { toca-discos 'record player' } \\
\text { lava-platos 'dishwasher' } \\
\text { abre-cartas 'letter opener' } \\
\text { tapa-bocas 'scarf/muffler' } \\
\text { cuenta-gotas 'dropper' }\end{array}$ & $\begin{array}{l}\text { apagavelitas } \\
\text { paraguitas } \\
\text { tocadisquitos } \\
\text { lavaplatitos } \\
\text { abrecartitas } \\
\text { tapaboquitas } \\
\text { cuentagotitas }\end{array}$ \\
\hline $\begin{array}{l}\text { Minus its plural morphology, } \\
\mathrm{N}_{2} \text { is disyllabic and ends in } e\end{array}$ & $\begin{array}{l}\text { guarda-bosques 'forest ranger' } \\
\text { para-choques 'bumper' } \\
\text { porta-llaves 'keyring' }\end{array}$ & $\begin{array}{l}\text { guardabosquecitos } \\
\text { parachoquecitos } \\
\text { portallavecitas }\end{array}$ \\
\hline
\end{tabular}

One apparent kind of counterevidence to this hypothesis involves synthetic compounds such as sheep-stealer, theater-goer, and evildoer, in which the agentive suffix does not join with the verbal base in isolation: ${ }^{*}$ stealer,${ }^{*}$ goer,${ }^{*}$ doer. Such cases might, however, be brought into conformity with the hypothesis that (1) is invariably valid by appealing to the distinction between absolute and conjunct forms. An absolute form is used in isolation from any compounded formatives; a conjunct form is used in the presence of 
compounded formatives. Many languages exhibit absolute/conjunct distinctions in their morphology (Stump 1995: 264-73; 2001: 119-26). In Sanskrit, for example, a verb's gerund has both an absolute form in $-t v \bar{a}$ (used in the absence of any compounded preverbs, e.g. patitva ' 'having flown') and a conjunct form in $-y a$ (used in the presence of one or more compounded preverbs, e.g. ni-patya 'having flown down'). Once a distinction is drawn between absolute and conjunct forms, one can say that in English, the agentive derivatives of the verbs steal, go, and $d o$ have conjunct forms but lack absolute forms; in this way, one can maintain that even derivatives such as sheep-stealer conform to (1).

This hypothesis, however, is dramatically disconfirmed by the evidence of ordinal derivation. A survey of ordinal derivation in over seventy languages reveals that when a compound cardinal numeral is the base of derivation, the expression of ordinal derivation is highly variable. Thus, suppose that each language with ordinal derivation has a function $\operatorname{Ord}$ such that where $\mathrm{X}$ is a cardinal numeral, $\operatorname{Ord}(\mathrm{X})$ is the ordinal counterpart of X; on that assumption, (1) does not suffice to define the form of ordinal derivatives for compound cardinal numerals. Indeed, as I now show, languages exhibit great diversity in the rules of composition that they employ for the evaluation of the function $\mathrm{Ord}$.

\section{Ordinal derivation}

\section{I Some preliminaries}

Before considering the formation of ordinal derivatives from compound cardinal numerals, it is important to note the large variety of ways in which natural languages form complex cardinal numerals. Some languages have no cardinal numeral morphology at all; an example is Andamanese, whose cardinal numeral system is reported to consist of the two lexical items in (7).

(7) The cardinal numerals of Andamanese (according to Bloch, cited by Stampe 1976: 596)

ūbatūl ' 1 ' $\quad$ ikpōr ' 2 or more'

Most languages, however, have rich systems of cardinal numeral morphology, allowing larger numbers to be named through the systematic combination of numerals that name smaller numbers. The nature of such combinations varies widely across languages. For instance, Stampe (1976) cites the words for 'eighteen' in the languages in (8):

(8) The cardinal numeral 'eighteen' in fifteen languages (cf. Stampe 1976: 594f)

Ono [Trans-New

Guinea]

Sora (a)

[Austro-Asiatic;

Munda] mete etke so keio mane hand 2 and foot

so ḑitne karewe

mi-jen yagi

whole and

toe 3

1 -foot 3 


\begin{tabular}{|c|c|c|}
\hline Welsh (a) & tri ar bym-theg & 3 on $5-10$ \\
\hline Classical Greek & 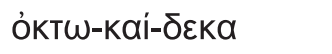 & 8 -and-10 \\
\hline Spanish & diez y ocho & 10 and 8 \\
\hline Nama [Khoisan] & [dìsi]-xhéisa-ca & {$[10]-8$-and } \\
\hline German & acht-zehn & $8-10$ \\
\hline Vietnamese & mư ời-tám & $10-8$ \\
\hline $\begin{array}{c}\text { [Austro-Asiatic; } \\
\text { Mon-Khmer] }\end{array}$ & & \\
\hline Lithuanian & aštuna-lika & 8-left \\
\hline Ainu & tu-pesan-ishama-wan & $\begin{array}{l}\text { 2-from.[10]-and } \\
\text {-both.[hands] }\end{array}$ \\
\hline Latin & duo-de-vi-ginti & 2 -from-2-10 \\
\hline Finnish & kah-deksan toista & $\begin{array}{l}\text { 2-from. } 10 \text { of. } \\
\text { the. } 2 \text { nd. [10] }\end{array}$ \\
\hline Sora (b) & miggəl-tuḍru & $12-6$ \\
\hline Breton & tri-ouec'h & $3-6$ \\
\hline Welsh (b) & deu-naw & $2-9$ \\
\hline
\end{tabular}

These examples demonstrate at least three dimensions along which languages vary in the definition of their cardinal numerals. First, languages differ in the choice of their numeral base. Most of the cardinal numeral systems exemplified in (8) express 'eighteen' decimally (in base 10), but Sora (variety (b)) instead expresses it duodecimally (in base 12). The languages represented here also vary in the way in which arithmetic operations are evoked for the interpretation of complex cardinal numerals: most express the numeral 'eighteen' additively, but Breton and Welsh (b) express it multiplicatively, Ono expresses it through the use of both multiplication and addition, and Latin expresses it through the use of both multiplication and subtraction. Finally, the languages vary in the ways in which they express a particular arithmetic operation: Spanish, for example, expresses the additive operation in 10+8 through the use of an overt conjunction; Vietnamese expresses the additive operation in $10+8$ purely by means of the ordering of its conjuncts, with the smaller addend following the larger one (in contrast to tám mươi ' 80 ', literally ' 810 '); and German expresses the additive operation in $8+10$ through the use of the allomorph $z e h n$ (in contrast to $-z i g$, which is instead used for the expression of the multiplicand as in numerals such as achtzig ' 80 ').

My objective here is to examine a further layer of diversification in the definition of languages' numeral systems, namely that of the formation of ordinal numerals (numerals that don't simply specify cardinality, but indicate a position in an ordered sequence). In particular, I shall develop a typological classification of the ways in which complex numerals such as those in (8) form their ordinals; in formal terms, this is a classification of the kinds of rules of composition that languages use in deriving ordinals from complex cardinals. ${ }^{2}$ 
Many languages have distinct cardinal and ordinal numerals, but not all do; for instance, there are no special ordinal numerals in the Peruvian language isolate Urarina (Olawsky 2006: 282), nor in the Chapacura-Wanham language Wari' of Brazil (Everett \& Kern 1997: 349), nor in the Sino-Tibetan languages Qiang (LaPolla 2003: 64) and Dumi (van Driem 1993: 88). Many languages also distinguish ordinals from cardinals for certain numbers only. For instance, in the Babungo language (Niger-Congo; Cameroon), only 'one' has an ordinal counterpart (Schaub 1985: 240); in Lavukaleve (East Papuan), ordinals are distinguished from cardinals only for 'one' through 'ten', beyond which the cardinal numerals serve both cardinal and ordinal functions (Terrill 2003: 53); in Panamint (Uto-Aztecan), special ordinals exist only for 'one' through 'ten' and for multiples of ten (Dayley 1989: 161-7). Even so, a great many languages associate a distinct ordinal numeral with every one (or nearly) of their cardinal numerals; it is with those languages that I am concerned here.

\subsection{External ordinal marking}

Conceptually, the simplest way of forming the ordinal counterpart of a complex cardinal numeral $n$ is by means of an operation applying to $n$ as an unanalyzed whole. I shall refer to ordinal marking arising through such operations as EXTERNAL ordinal marking. The clearest cases of external ordinal marking are those involving a circumfix which straddles an entire cardinal numeral, however complex it may be. Thus, in Kanuri, ordinals are formed by attaching a circumfix to the corresponding cardinal; the circumfix consists of the prefix kán- and the suffix -mi, which join with both simplex and complex cardinals, as in (9).

(9) Kanuri [Nilo-Saharan] exhibits ordinal marking of the EXTERNAL CIRCUMFIXAL type

\begin{tabular}{|c|c|c|c|c|}
\hline Cardinal: & $\begin{array}{l}\text { tiló ' } 1 \text { ' } \\
1\end{array}$ & $\begin{array}{l}\text { fíndi } \\
20\end{array}$ & $\begin{array}{l}\text { fíndin (lúkko) tilôn } \\
20 \quad \text { (\&) } 1\end{array}$ & '21' \\
\hline Ordinal: & $\begin{array}{l}\text { kán-tiló-mi '1st' } \\
\text { ORD-1-ORD }\end{array}$ & $\begin{array}{l}\text { kán-fíndi-mi '20th' } \\
\text { ORD-20-ORD }\end{array}$ & $\begin{array}{l}\text { kán-fíndin (lúkko) tilôn-mi } \\
\text { ORD-20 } \quad \text { (\&) } 1 \text {-ORD }\end{array}$ & ‘21st' \\
\hline Sources: & \multicolumn{4}{|c|}{ Cyffer 2007: 1106-07; Hutchison 1981: 76-77, 202-03. } \\
\hline \multicolumn{5}{|c|}{$\begin{array}{l}\text { Additional language of this type: Old Georgian [Kartvelian]; Fähnrich 1991: 154-55. Fähnrich } \\
\text { mentions that alongside the external circumfixal pattern me-oc-da-ert-ey [ORD-20-\&-1-ORD], } \\
\text { the pattern oc da me-ert-ey [20-\&-ORD-1-ORD] is also attested in Old Georgian; this pattern is } \\
\text { comparable to a Modern Georgian pattern cited in (22a) below. }\end{array}$} \\
\hline
\end{tabular}


Thus, Kanuri doesn't need a rule of composition for the derivation of ordinals from complex cardinals; instead, all cardinals, complex or not, involve a single word-formation rule, as in (10).

(10) Definition of $\boldsymbol{O r d}$ in Kanuri: $\boldsymbol{O} r d(\mathrm{X})=k \not ́ n-\mathrm{X}-m i$

\subsection{Internal ordinal marking}

Despite the conceptual simplicity of deriving ordinals from compound cardinals treated as unanalyzed wholes, a very common pattern of ordinal marking for compound cardinals involves the use of ordinal marking on one or more of the compound's individual constituents. I refer to this pattern of ordinal marking as INTERNAL marking.

There are numerous subtypes of internal ordinal marking. One extremely common subtype involves ordinal marking on exactly one constituent of the numeral compound, typically a peripheral constituent. Thus, in many languages, ordinal marking is situated on a numeral compound's right-peripheral constituent. In English, for example, the ordinal counterpart of the compound cardinal twenty-one is twenty-first, in which only the compound's final constituent exhibits ordinal marking. Similar examples are found in the other languages listed in (11).

(11) English exhibits ordinal marking of the INTERNAL RIGHT-PERIPHERAL type

\begin{tabular}{|c|c|c|c|}
\hline Cardinal: & one & twenty & twenty-one \\
\hline Ordinal: & first & twentieth & twenty-first \\
\hline \multicolumn{4}{|c|}{ Additional languages of this type: } \\
\hline Kurux & & [Dravidian] & Hahn 1985: 87-90 \\
\hline \multicolumn{2}{|c|}{ West Greenlandic } & [Eskimo-Aleut] & Fortescue 1984: 304-07. \\
\hline \multicolumn{2}{|l|}{ Latvian } & [IE; Baltic] & Fennell \& Gelsen 1980: 159, 230, 357, 366, 377. \\
\hline \multicolumn{2}{|c|}{ Lithuanian } & [IE; Baltic] & Senn 1966: 212-18. \\
\hline \multicolumn{2}{|l|}{ Afrikaans } & [IE; Germanic] & Donaldson 1993: 420-24. \\
\hline \multicolumn{2}{|l|}{ Dutch } & [IE; Germanic] & Fehringer 1999: 58-60. \\
\hline \multicolumn{2}{|l|}{ German } & [IE; Germanic] & Hammond 1981: 167-72. \\
\hline \multicolumn{2}{|c|}{ Norwegian } & [IE; Germanic] & Strandskogen \& Strandskogen 1986: 147-49. \\
\hline \multicolumn{2}{|l|}{ Swedish } & [IE; Germanic] & Holmes \& Hinchliffe 2003: 196-206. \\
\hline \multicolumn{2}{|l|}{ Bulgarian } & [IE; Slavic] & Rå Hauge 1999: 76. \\
\hline \multicolumn{2}{|c|}{ Lower Sorbian } & [IE; Slavic $]$ & Janaš 1976: 143-65. \\
\hline
\end{tabular}




$\begin{array}{|lll|}\text { Russian } & \text { [IE; Slavic] } & \text { Wade 1992: 193-218. } \\ \text { Serbian } & \text { [IE; Slavic] } & \text { Hammond 2005: 255-67. } \\ \text { Slovene } & {[\text { IE; Slavic] }} & \text { Herrity 2000: 126-37. } \\ \text { Ukrainian } & \text { [IE; Slavic] } & \text { Pugh \& Press 1999: 189-98. } \\ \text { Modern Georgian (a) } & \text { [Kartvelian] } & \text { Aronson 1989: 147-48, 279-81; 1991: 263-65; } \\ & & \text { Fähnrich 1987: 62-64. } \\ \text { Nenets } & \text { [Uralic] } & \text { Décsy 1966: 43. }\end{array}$

In these languages, a rule of composition of the type in (1) is responsible for the derivation of ordinals for complex cardinals. Thus, the Ord function has the following recursive definition in English:

(12) (Recursive) definition of Ord in English:

a. Default rule of derivational exponence: $\operatorname{Ord}(\mathrm{X})=\mathrm{X}-(e)$ th (where $e$ appears after $i$ )

b. Rules of derivational exponence overriding (12a):

$$
\begin{aligned}
& \operatorname{Ord}(\text { one })=\text { first } \\
& \operatorname{Ord}(\text { tmo })=\text { second } \\
& \operatorname{Ord}(\text { three })=\text { third }
\end{aligned}
$$

c. Rule of composition overriding $(12 \mathrm{a}): \operatorname{Ord}([\mathrm{X} Y])=[\mathrm{X} \operatorname{Ord}(\mathrm{Y})]$

Though I've characterized the ordinal marking in (11) as right-peripheral, there is an apparent alternative analysis: that of assuming that ordinal marking is always situated on the numeral denoting the smaller of two numbers. It is clear, though, that for the languages cited here, the simpler analysis is that ordinal marking is situated at a compound numeral's right periphery. Consider first English multiplicative compounds such as two hundred: these, too, exhibit right-peripheral ordinal marking (tmo hundredth), even though the multiplicand hundred denotes a larger number than the multiplier two. Moreover, the English teens are additive numerals in which the smaller addend precedes the larger, yet here too, ordinal morphology is situated at the right periphery, as in seventeenth. And finally, several Germanic and Slavic languages express ' 21 ' as 'one and twenty', with the smaller addend preceding; yet here again, the ordinal counterpart involves the ordinal form of the final addend rather than that of the smaller addend. These same languages express ' 101 ' as 'hundred (and) one', whose ordinal counterpart involves the ordinal form of 'one', as in English. (Norwegian has alternative forms for 'twenty-first', one similar to English, the other to German.)

Internal ordinal marking is not always right-peripheral. Additive numerals in some languages are marked left-peripherally (on the larger of two addends), as for example in (13); see also the Breton evidence in $§ 3.5$. 
(13) Anywa [Nilo-Saharan; Eastern Sudanic] exhibits ordinal marking of the INTERNAL LEFT-PERIPHERAL type in additive numerals

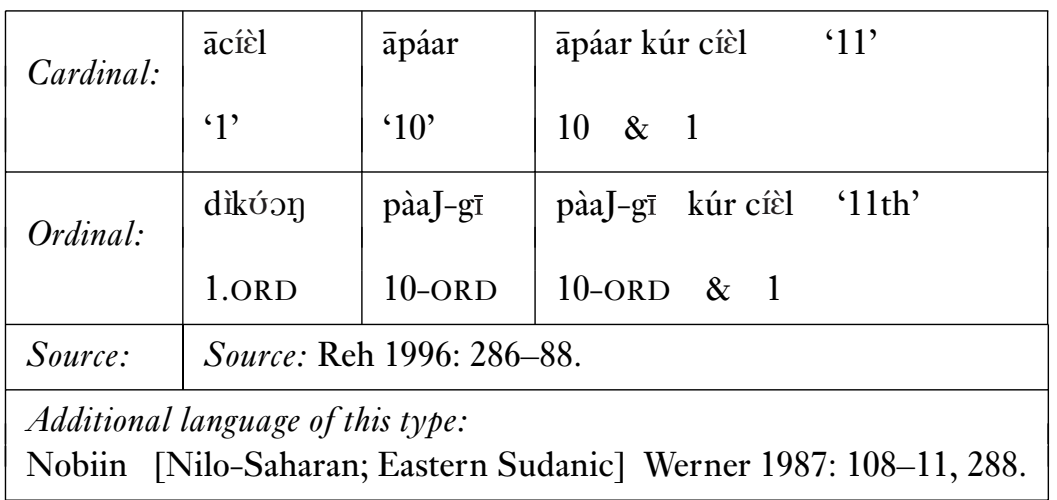

\subsection{Extended internal ordinal marking}

The examples of internal ordinal marking in (11) and (13) are SIMPLE in the sense that in each instance, only a single constituent carries ordinal marking in the ordinal form of a numeral compound. But some languages instead exhibit EXTENDED internal ordinal marking, in which two or more constituents of a numeral compound exhibit ordinal marking.

There are, in fact, three different subtypes of extended internal ordinal marking. The primary distinction is between extended internal ordinal marking which applies to operands of both multiplication and addition and marking which only applies to operands of addition (i.e. to addends). Consider first the Finnish example in (14). As this example shows, Finnish has extended internal ordinal marking, and the application of ordinal marking to a constituent is insensitive to whether that constituent serves as an operand of addition or multiplication. In Modern Greek, by contrast, only operands of addition are eligible for ordinal marking, as the example in (15) shows. Thus, extended internal ordinal marking may be OPERATION-INSENSITIVE (as in (14)) or OPERATION-SENSITIVE (as in (15)).

(14) Finnish [Uralic; Finnic] exhibits EXTENDED INTERnAL ordinal marking (OPERATION-INSENSITIVE):

\begin{tabular}{|l|ll|}
\hline Cardinal: & $\begin{array}{l}\text { kolme-tuhatta sata-kolme-kymmentä-neljä } \\
\text { 3-1000.PART.SG 100-3-10.PART.SG-4 }\end{array}$ & '3134’ \\
\hline Ordinal: & $\begin{array}{l}\text { kolmas-tuhannes sadas-kolmas-kymmenes-neljäs } \\
\text { 3.ORD-1000.ORD 100.ORD-3.ORD-10.ORD-4.ORD }\end{array}$ & '3134th' \\
\hline
\end{tabular}


Sources: Sulkala \& Karjalainen 1992: 344-7; Karlsson 1999: 129-35.

Karlsson (1999: 134) notes that Finnish also allows long ordinal numerals in which only the final constituent carries ordinal marking, e.g. kolmetuhatta satakolmekymmentäneljäs '3134th'. Alongside kahdes-kymmenes-ensimmäinen [2.ORD-10.ORD-first] '21st' and kahdes-kymmenes-toinen [2.ORD-10.ORD-second] '22nd', kahdes-kymmenes-yhdes [2.ORD-10.ORD-1.ORD] '21st' and kahdes-kymmenes-kahdes [2.ORD-10.ORD-2.ORD] '22nd' are also possible; see (22b) below concerning these.

Additional language of this type: Vod [Uralic] Ariste 1968: 61-6.

(15) Modern Greek [IE; Hellenic] exhibits EXTENDED INTERNAL ordinal marking (OPERATION-SENSITIVE):

\begin{tabular}{|c|c|c|c|c|c|}
\hline Cardinal: & $\begin{array}{l}\text { xília } \\
1000\end{array}$ & $\begin{array}{l}\text { tetrakósia } \\
4.100\end{array}$ & $\begin{array}{l}\text { penínda } \\
5.10\end{array}$ & $\begin{array}{l}\text { téssera } \\
4\end{array}$ & ' $1,454^{\prime}$ \\
\hline Ordinal: & $\begin{array}{l}\text { xiliostós } \\
\text { 1000.ORD }\end{array}$ & $\begin{array}{l}\text { tetrakosiostós } \\
\text { 4.100.ORD }\end{array}$ & $\begin{array}{l}\text { pendikostós } \\
\text { 5.10.ORD }\end{array}$ & $\begin{array}{l}\text { tétartos } \\
\text { 4.ORD }\end{array}$ & $' 1,454 \mathrm{th}^{\prime}$ \\
\hline \multicolumn{6}{|c|}{ Source: Joseph \& Philippaki-Warburton 1987: 208.} \\
\hline $\begin{array}{l}\text { Additional lar } \\
\text { Old Norse } \\
\text { Latin } \\
\text { Portuguese } \\
\text { Spanish } \\
\text { Czech* }\end{array}$ & $\begin{array}{l}\text { zges of this type: } \\
\text { [IE; Germanic] } \\
\text { [IE; Italic] } \\
\text { [IE; Italic] } \\
\text { [IE; Italic] } \\
\text { [IE; Slavic] }\end{array}$ & $\begin{array}{l}\text { Gordon 1957: } \\
\text { Wheelock 196 } \\
\text { Perini 2002: } 1 \\
\text { Butt \& Benjar } \\
\text { Naughton 20 } \\
\text { numbers 21-9 } \\
\text { compounds i } \\
\text { jed(e)nadvacet } \\
\text { compounds, } \\
\text { e.g. jednadvac } \\
\text { Swan 2002: } 1\end{array}$ & $\begin{array}{l}-93 . \\
84-85 \\
11 . \\
1988: 94-100 . \\
16,119 . \text { Nauq } \\
\text { e also express } \\
\text { hich the lowe } \\
\text {; in the ordin } \\
\text { the final add } \\
08 \text {; Bielec } 199\end{array}$ & $\begin{array}{l}\text { ton note } \\
\text { ole by me } \\
\text { constitue } \\
\text { counter } \\
\text { nd carrie } \\
: 240-56 .\end{array}$ & $\begin{array}{l}\text { that in Czech, the } \\
\text { ns of additive } \\
\text { t precedes, e.g. } \\
\text { rts of these } \\
\text { ordinal marking, }\end{array}$ \\
\hline
\end{tabular}


Among languages in which extended internal ordinal marking is operation-sensitive, there is a second distinction: in some such languages, the eligibility of an addend for ordinal marking may depend on how large a number it denotes. In Portuguese numeral compounds, all addends, no matter how large a number they denote, are eligible for ordinal marking; for example, the ordinal form of the numeral ' 1,566 th' in (16) has ordinal marking on all of its addends. In Czech numeral compounds, by contrast, a nonfinal addend is eligible for ordinal marking only if it denotes a multiple of ten less than 100; for example, the ordinal form of the numeral '1,964th' in (17) has ordinal marking on its last two addends, but not on its first two. Thus, extended internal ordinal marking which is operation-sensitive may be UNLIMITED (as in Portuguese) or LIMITED (as in Czech).

(16) Portuguese exhibits Unlimited extended internal ordinal marking (operation-sensitive):

\begin{tabular}{|l|lllllll|}
\hline \multirow{2}{*}{ Cardinal: } & mil, & quinhentos & e & sessenta & e & seis & '1566' \\
& 1000 & 500 & $\&$ & 60 & $\&$ & 6 & \\
\hline \multirow{2}{*}{ Ordinal: } & milésimo & quingentésimo & sexagésimo & sexto & '1566th' \\
& 1000. ORD & 500. ORD & 60. ORD & 6.ORD & \\
\hline
\end{tabular}

(Perini 2002: 110)

(17) Czech exhibits LIMITED extended internal ordinal marking (operation-sensitive):

\begin{tabular}{|l|llllll|}
\hline \multirow{2}{*}{ Cardinal: } & tisíc & devět & set & šedesát & čtyři & '1964' \\
& 1000 & 9 & 100 & 60 & 4 & \\
\hline \multirow{2}{*}{ Ordinal: } & tisíc & devět & set & šedesátý & čtvrtý & '1964th' \\
& 1000 & 9 & 100 & $60.0 R D$ & 4.ORD & \\
\hline
\end{tabular}

(Naughton 2005: 119)

In these languages, a rule of composition rather different from the English rule (12c) is responsible for the derivation of ordinals for complex cardinals. Thus, the Ord function has the following (partial) recursive definition in Finnish: 
(18) (Partial recursive) definition of $\operatorname{Ord}$ in Finnish:

a. Default rule of derivational exponence:

$\operatorname{Ord}(\mathrm{X})=\mathrm{X}^{\prime}-s$, where $\mathrm{X}^{\prime}$ is the inflectional stem of $\mathrm{X}$

b. Rules of derivational exponence overriding (18a):

$$
\begin{aligned}
& \operatorname{Ord}(y k s i)=\text { ensimmäinen ['first'] } \\
& \operatorname{Ord}(k a k s i)=\text { toinen ['second'] }
\end{aligned}
$$

c. Rule of composition overriding $(18 \mathrm{a}): \quad \operatorname{Ord}([\mathrm{X} Y])=[\operatorname{Ord}(\mathrm{X}) \operatorname{Ord}(\mathrm{Y})]$

Similarly, the Ord function has (19) as its (partial) recursive definition in Modern Greek:

(19) (Partial recursive) definition of Ord in Modern Greek:

a. Default rule of derivational exponence:

$\operatorname{Ord}(\mathrm{X})=\mathrm{X}^{\prime}-t 0^{-}$, where $\mathrm{X}^{\prime}$ is $\mathrm{X}$ 's combining form.

b. Rules of derivational exponence overriding (19a):

$$
\begin{aligned}
& \operatorname{Ord}(\text { enas })=\text { prótos ['first'] } \\
& \operatorname{Ord}(\delta j o ́)=\delta e ́ f t e r o s[\text { ['second'] }
\end{aligned}
$$

c. Rules of composition overriding (19a):

Where $|\mathrm{X}|$ is the number denoted by numeral $\mathrm{X}$ and

$|[\mathrm{Y} \mathrm{Z}]|=|\mathrm{Y}|+|\mathrm{Z}|$,

$\operatorname{Ord}([\mathrm{Y} Z])=[\operatorname{Ord}(\mathrm{Y}) \operatorname{Ord}(\mathrm{Z})]$;

otherwise, $\operatorname{Ord}([\mathrm{W} \mathrm{X}])=[\mathrm{W} \operatorname{Ord}(\mathrm{X})]$

\subsection{Two types of structure sensitivity}

The Modern Greek rule of composition in (19a) is sensitive to the arithmetic operation involved in a compound numeral. Rules of composition in other languages exhibit other sorts of sensitivity. In Breton, for example, a numeral compound exhibits internal ordinal marking on the addend immediately preceding an overt mark of addition ( $m a r$ ' 'on', $h a$ 'and'); otherwise it has right-peripheral marking. The examples in (20) illustrate. As the examples in (20a) show, there is a natural syntactic break in Breton numerals containing an overt mark of addition: when a phrase-internal (cardinal or ordinal) numeral modifies the head of a noun phrase, the modified head noun occupies this natural break; thus, 
Breton ordinal marking is right-peripheral within the part of the numeral preceding this break. Various ways of formulating this generalization are imaginable; these are orthogonal to the issue under scrutiny here.

(20) Breton [IE; Celtic] exhibits internal ordinal marking on the addend immediately preceding an overt mark of addition (mar 'on', ha 'and'); otherwise it has rightperipheral marking.

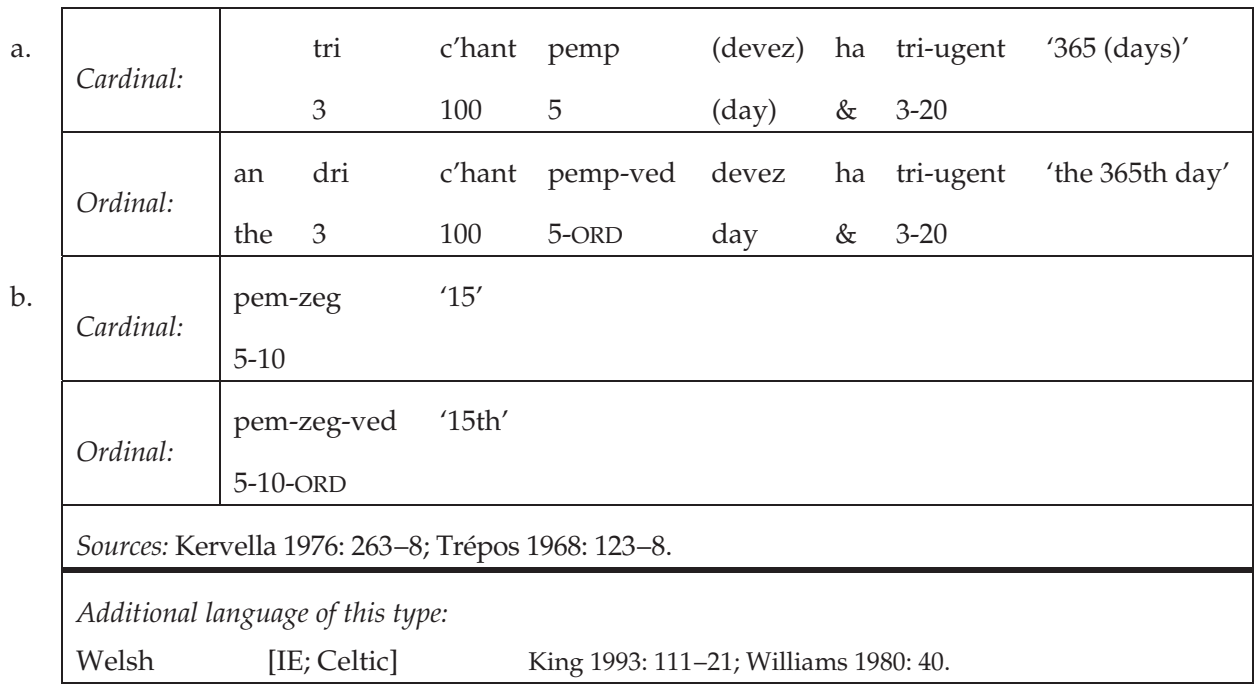

The structure sensitivity in (20) involves the localization of ordinal marking among a numeral compound's conjuncts. Breton ordinals also exhibit a second, quite different type of structure sensitivity: a numeral may have one ordinal marking when it appears in isolation and a different ordinal marking when it appears as a member of a compound. In Breton, the cardinal unan ' 1 ' has the suppletive ordinal kentan 'first' when used in isolation; but as part of an additive compound, the ordinal form of unan is the fully regular form unanved; by contrast, the cardinal daou ' 2 ' has a suppletive ordinal eil that is used both in isolation and as part of an additive compound (though there is some dialectal variation in this regard). Similar facts hold true in Welsh. The examples in $(21 \mathrm{a}, \mathrm{b})$ illustrate. As these examples show, certain ordinals have separate absolute and conjunct forms. Similar absolute/conjunct alternations are of course familiar in other areas of morphology (Stump 1995: 264ff; 2001: 119ff); for instance, Latin has absolute faciō 'I do' but conjunct -ficiō (perficio' 'I accomplish', adficiō 'I affect', efficiō' 'I perform'), French has absolute dites 'you say' but conjunct -disez (contredisez 'you contradict', interdisez 'you prohibit', médisez 'you speak ill of'), Sanskrit has absolute nìtvā 'having led' but conjunct -nīya (pariniya 'having married', abhinīya 'having brought near', avaniya 'having led down into'), and so on. 
(21) Languages with separate absolute and conjunct ordinals

a. Breton [IE; Celtic]

\begin{tabular}{|c|c|c|c|c|c|c|c|}
\hline Cardinal: & \multicolumn{2}{|l|}{$\begin{array}{l}\text { unan } \\
1\end{array}$} & $\begin{array}{l}\text { unan warn-ugent } \\
1 \quad \text { on- } 20\end{array}$ & $' 21^{\prime}$ & $\begin{array}{l}\text { daou } \\
\text { 2.MASC }\end{array}$ & $\begin{array}{l}\text { daou warn-ugent } \\
\text { 2.MASC on-20 }\end{array}$ & '22' \\
\hline \multirow{2}{*}{ Ordinal: } & absolute: & $\begin{array}{l}\text { kentañ } \\
1 . \text { ORD }\end{array}$ & & & \multirow{2}{*}{$\begin{array}{l}\text { eil } \\
\text { 2.ORD }\end{array}$} & \multirow{2}{*}{$\begin{array}{l}\text { eil warn-ugent } \\
\text { 2.ORD on-20 }\end{array}$} & \multirow[t]{2}{*}{ '22nd' } \\
\hline & conjunct: & $\begin{array}{l}\text { unan-ved } \\
\text { 1-ORD }\end{array}$ & $\begin{array}{l}\text { unan-ved warn-ugent } \\
\text { 1-ORD on-20 }\end{array}$ & '21st' & & & \\
\hline
\end{tabular}

Sources: Kervella 1976: 263-8; Trépos 1968: 123-8. Trépos also notes (p.127) the incidence of the patterns eilved warn-ugent, daouved warn-ugent, and diouved warn-ugent '22nd'.

b. Welsh [IE; Celtic]

\begin{tabular}{|c|c|c|c|c|c|c|}
\hline Cardinal: & \multicolumn{2}{|l|}{ un } & $\begin{array}{l}\text { un ar hugain } \\
1 \text { on } 20\end{array}$ & $\begin{array}{l}\text { dau } \\
\text { 2.MASC }\end{array}$ & $\begin{array}{l}\text { dau ar hugain } \\
\text { 2.MASC on } 20\end{array}$ & '22' \\
\hline \multirow{2}{*}{ Ordinal: } & absolute: & $\begin{array}{l}\text { cyntaf } \\
\text { 1.ORD }\end{array}$ & & \multirow{2}{*}{ 2.ORD } & \multirow{2}{*}{$\begin{array}{l}\text { ail ar hugain } \\
\text { 2.ORD on } 20\end{array}$} & \multirow[t]{2}{*}{ '22nd' } \\
\hline & conjunct: & $\begin{array}{l}\text { un-fed } \\
1-O R D\end{array}$ & $\begin{array}{l}\text { un-fed ar hugain '21st' } \\
\text { 1-ORD on } 20\end{array}$ & & & \\
\hline
\end{tabular}

In some systems, conjunct ordinals alternate optionally with their absolute counterparts. Thus, in Modern Georgian, the fully regular circumfixal form me-ert-e [ORD-1-ORD] ' 1 st' optionally appears as a conjunct alternative to the suppletive ordinal p'irveli '1st'. In Finnish, $y k s i$ ' 1 ' and $k a k s i$ ' 2 ' each have two alternative ordinals: an absolute form (ensimmäinen and toinen) and a conjunct form ( $y$ hdes and kahdes). The absolute form is used in isolation; the conjunct form is used in multiplicative compounds; and in additive compounds either the absolute form or the conjunct form may be used. The Georgian and Finnish facts are schematized in (22). 
(22) Languages with optional conjunct ordinals

a. Modern Georgian [Kartvelian]

\begin{tabular}{|c|c|c|c|c|}
\hline Cardinal: & \multicolumn{2}{|l|}{ erti } & $\begin{array}{l}\text { oc-da-erti } \\
20-\&-1\end{array}$ & '21' \\
\hline \multirow{2}{*}{ Ordinal: } & absolute: & $\begin{array}{l}\text { p'irveli } \\
\text { 1.ORD }\end{array}$ & $\begin{array}{l}\text { oc-da-p'irveli } \\
\text { 20-\&-first }\end{array}$ & '21st' \\
\hline & conjunct: & $\begin{array}{l}\text { me-ert-e } \\
\text { ORD-1-ORD }\end{array}$ & $\begin{array}{l}\text { oc-da-me-ert-e } \\
\text { 20-\&-ORD-1-ORD }\end{array}$ & '21st' \\
\hline \multicolumn{5}{|c|}{$\begin{array}{l}\text { Sources: Aronson 1989: } 147-48,279-81 ; 1991 \text { : 263-65; Fähnrich 1987: 62-64; 1991: 154-55. } \\
\text { The pattern oc-da-me-ert-e is attested in Old Georgian as oc da me-ert-ey '21st', } \\
\text { alongside the external marking pattern of me-oc-da-ert-ey; cf. (9) above. }\end{array}$} \\
\hline
\end{tabular}

b. Finnish [Uralic]

\begin{tabular}{|c|c|c|c|c|}
\hline \multirow{2}{*}{ Cardinal: } & \multicolumn{2}{|l|}{$\begin{array}{l}\text { yksi } \\
1\end{array}$} & $\begin{array}{l}\text { kaksi-kymmentä yksi } \\
2-10\end{array}$ & '21' \\
\hline & \multicolumn{2}{|l|}{$\begin{array}{l}\text { kaksi } \\
2\end{array}$} & $\begin{array}{l}\text { kaksi-kymmentä kaksi } \\
2-10 \quad 2\end{array}$ & '22' \\
\hline \multirow{4}{*}{ Ordinal: } & \multirow{2}{*}{ absolute: } & $\begin{array}{l}\text { ensimmäinen } \\
\text { 1.ORD }\end{array}$ & $\begin{array}{l}\text { kahdes-kymmenes-ensimmäinen } \\
\text { 2.ORD-10.ORD-1.ORD }\end{array}$ & '21st' \\
\hline & & $\begin{array}{l}\text { toinen } \\
\text { 2.ORD }\end{array}$ & $\begin{array}{l}\text { kahdes-kymmenes-toinen } \\
\text { 2.ORD-10.ORD-2.ORD }\end{array}$ & '22nd' \\
\hline & \multirow{2}{*}{ conjunct: } & $\begin{array}{l}\text { yhdes } \\
\text { 1.ORD }\end{array}$ & $\begin{array}{l}\text { kahdes-kymmenes-yhdes } \\
\text { 2.ORD-10.ORD-1.ORD }\end{array}$ & '21st' \\
\hline & & $\begin{array}{l}\text { kahdes } \\
\text { 2.ORD }\end{array}$ & $\begin{array}{l}\text { kahdes-kymmenes-kahdes } \\
\text { 2.ORD-10.ORD-2.ORD }\end{array}$ & '22nd' \\
\hline
\end{tabular}

In view of the two sorts of structure sensitivity that Breton ordinals exhibit, the Breton definition of the Ord function in (23) is different from those of (12), (18), and (19). In this definition, the function $\boldsymbol{O r d}_{\text {conjunct }}$ applies to a cardinal numeral to yield the 
corresponding conjunct ordinal; by default, $\operatorname{Ord}_{\text {conjunct }}(\mathrm{X})=\operatorname{Ord}(\mathrm{X})($ as in (23a)), but this default is overridden when $\mathrm{X}=$ unan 'one' (as in (23b)).

(23) (Partial recursive) definition of $\mathrm{Ord}$ in Breton:

a. Default rules of derivational exponence:

$$
\begin{aligned}
& \operatorname{Ord}(\mathrm{X})=\mathrm{X} \text {-ved } \\
& \operatorname{Ord}_{\text {conjunct }}(\mathrm{X})=\operatorname{Ord}(\mathrm{X})
\end{aligned}
$$

b. Rules of derivational exponence overriding (23a):

$$
\begin{array}{ll}
\operatorname{Ord}(\text { unan })=\text { kentañ } & \text { ['first'; absolute] } \\
\operatorname{Ord} \text { conjunct }_{\text {(unan })=\text { unanved }} & \text { ['first'; conjunct] } \\
\operatorname{Ord}(\text { daou })=\text { eil } & \text { ['second'] } \\
\operatorname{Ord}(\text { tri })=\text { trede } & \text { ['third'] } \\
\operatorname{Ord}(\text { pevar })=\text { pevare } & \text { ['fourth'] }
\end{array}
$$

c. Rules of composition overriding (23a):

$\operatorname{Ord}([\mathrm{X}$ CONJ Y $])=\left[\operatorname{Ord}_{\text {conjunct }}(\mathrm{X}) \mathrm{CONJ} \mathrm{Y}\right]$; otherwise, $\operatorname{Ord}([\mathrm{X} Y])=[\mathrm{X} \operatorname{Ord}(\mathrm{Y})]$

\subsection{Order sensitivity}

In addition to operation sensitivity (\$3.4) and structure sensitivity (\$3.5), ordinal marking may exhibit sensitivity to the ordering of two addends. In Maltese (Afro-Asiatic; Semitic), ordinals are distinguished from cardinals in that they necessarily exhibit initial

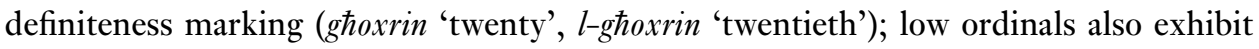
different stems from their cardinal counterparts (mieћed/maћda 'one' [masc./fem.], l-emwel 'first'). The ordinal form of an additive compound cardinal exhibits external

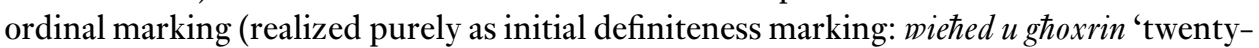
one', il-mieћed u ghoxrin 'twenty-first') unless the smaller addend follows, in which case ordinality is realized as both initial definiteness marking and ordinal marking of the smaller addend: mija $u$ miehed 'one hundred one', il-mija u l-emwel 'hundred and first';

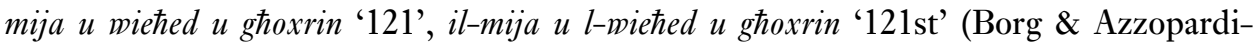
Alexander 1997: 266-71). Thus, in Maltese, the Ord function has (24) as its (partial) definition, where Definite(x) is the definiteness-marked form of X.

(24) (Partial recursive) definition of Ord in Maltese:

a. Default rule of derivational exponence: $\operatorname{Ord}(\mathrm{X})=$ Definite $(\mathrm{X})$

b. Rules of derivational exponence overriding (24a):

$$
\begin{array}{ll}
\operatorname{Ord}(\text { miehed })=\operatorname{Ord}(\text { matda })=\text { Definite }(\text { emmel }) & {[\text { ['first'] }} \\
\operatorname{Ord}(\dot{\text { zem }})=\text { Definite }(\text { tien }) & {[\text { 'second'] }} \\
\operatorname{Ord}(\text { tliet })=\text { Definite(tielet }) & \text { ['third'] }
\end{array}
$$


c. Rule of composition overriding (24a):

Where $|[\mathrm{Y} \mathrm{Z}]|=|\mathrm{Y}|+|\mathrm{Z}|$ and $|\mathrm{Y}|>|\mathrm{Z}|, \operatorname{Ord}([\mathrm{Y} Z])=$

$\operatorname{Definite}([\mathrm{Y} \operatorname{Ord}(\mathrm{Z})])$

\subsection{Interim summary}

The facts discussed so far suggest the typology of ordinal marking in compound numerals in (25). The evidence motivating this typology entails a range of different rules of composition for the compound ordinals in these languages; these are summarized for six languages in (26).

(25) Types of ordinal marking in compound numerals

\begin{tabular}{|l|c|c|c|c|c|c|c|}
\hline \multicolumn{1}{|c|}{ Language } & External & Internal & Extended & $\begin{array}{c}\text { Operation- } \\
\text { sensitive }\end{array}$ & Limited & Periphery & $\begin{array}{c}\text { Conjunct } \\
\text { morphology }\end{array}$ \\
\hline Kanuri & Yes & No & N/A & N/A & N/A & Circumfixal & No \\
\hline English & No & Yes & No & N/A & N/A & Right & No \\
\hline Anywa & No & Yes & No & N/A & N/A & Left & No \\
\hline Finnish & No & Yes & Yes & No & No & N/A & Optional \\
\hline Modern Greek & No & Yes & Yes & Yes & No & N/A & No \\
\hline Portuguese & No & Yes & Yes & Yes & No & N/A & No \\
\hline Czech & No & Yes & Yes & Yes & Yes & Right & No \\
\hline Brythonic \\
(Breton, \\
Welsh)
\end{tabular}


(26) Rules of derivational exponence and composition for ordinal derivation in six languages (where $|\mathrm{X}|$ is the number denoted by numeral $\mathrm{X}$ )

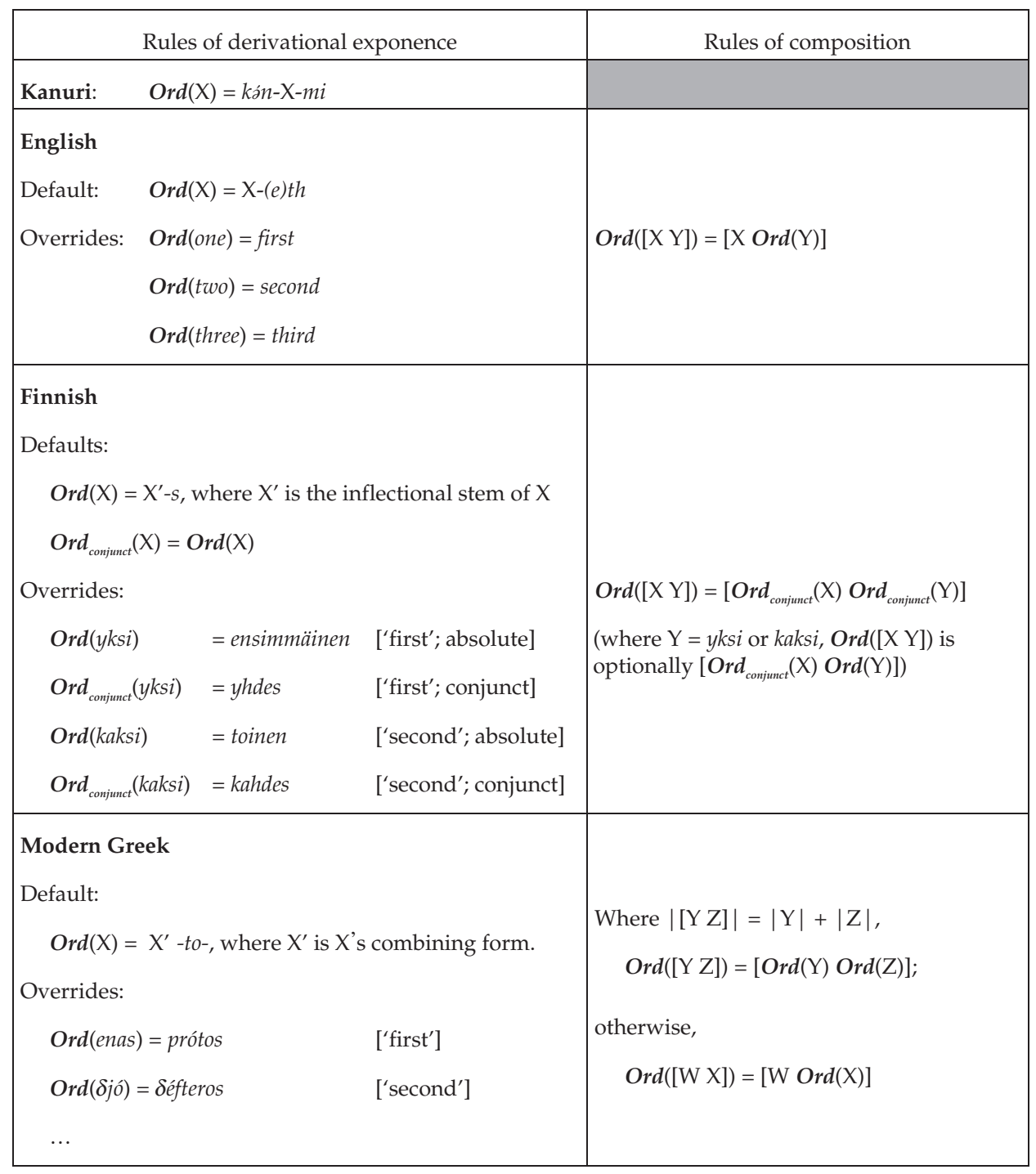




\begin{tabular}{|c|c|c|}
\hline \multicolumn{2}{|l|}{ Breton } & \\
\hline $\begin{array}{ll}\text { Defaults: } & \operatorname{Ord}(\mathrm{X})=\mathrm{X} \text {-ved } \\
& \operatorname{Ord}_{\text {conjinct }}(\mathrm{X})=\operatorname{Ord}(\mathrm{X}\end{array}$ & & \\
\hline Overrides: & & \\
\hline $\operatorname{Ord}($ unan $)=$ kentañ & ['first'; absolute] & $\operatorname{Ord}([\mathrm{X} C \mathrm{CONJ} \mathrm{Y}])=\left[\operatorname{Ord}_{\text {conjunct }}(\mathrm{X}) \mathrm{CONJ} \mathrm{Y}\right]$ \\
\hline $\operatorname{Ord}_{\text {conjunct }}($ unan $)=$ unanved & ['first'; conjunct] & $\operatorname{Ord}([\mathrm{X} Y])=[\mathrm{X} \operatorname{Ord}(\mathrm{Y})]$ \\
\hline $\operatorname{Ord}(d a o u)=e i l$ & ['second'] & \\
\hline $\operatorname{Ord}(t r i)=$ trede & ['third'] & \\
\hline $\operatorname{Ord}($ pevar $)=$ pevare & ['fourth'] & \\
\hline Maltese & & \\
\hline Default: $\operatorname{Ord}(\mathrm{X})=\operatorname{Definite}(\mathrm{X})$ & & \\
\hline Overrides: & & \\
\hline 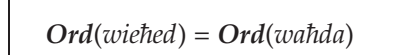 & & Where $|[Y Z]|=|Y|+|Z|$ and $|Y|>|Z|$, \\
\hline$=$ Definite (ewwel) & ['first'] & $\operatorname{Ord}([\mathrm{Y} Z])=\operatorname{Definite}([\mathrm{Y} \operatorname{Ord}(\mathrm{Z})])$ \\
\hline $\operatorname{Ord}(\dot{z} e w \dot{g})=$ Definite $($ tieni $)$ & ['second'] & \\
\hline $\operatorname{Ord}(t$ liet $)=$ Definite $($ tielet $)$ & ['third'] & \\
\hline
\end{tabular}

In the foregoing discussion, I have been assuming that compound numerals are morphological compounds and hence that rules of composition are morphological rules. Yet it is certainly possible that in some languages, compound numerals are generated in the syntax rather than in the morphology. For instance, the fact that the noun modified by a Breton cardinal or ordinal may be situated internally to the numeral (as in (20a)) and the fact that the parts of a Finnish complex numeral agree not only in ordinality but in number and case (Karttunen 2006) suggests that in these languages, compound numerals are generated syntactically. This is, however, an issue orthogonal to the need to postulate rules of composition; that is, whether one views a language's compound numerals as a product of morphology or of syntax, it is in any event necessary to postulate rules for the distribution of ordinal morphology with respect to a compound numeral's structure. Thus, if a compound cardinal numeral such as twenty-one is regarded as a syntactically complex expression of the form [Card Card Card], then the corresponding ordinal numeral must be seen as having the form [ord Card Ord]; that is, compound ordinal numerals must be assumed to instantiate the recursive structure [Ord Card Ord], the syntactic equivalent of the rule of composition in (12c). In this way, each of the rules of composition in (26) can be given a syntactic characterization, as in (27). 
(27) Ordinal composition in six languages (where $|\mathrm{X}|$ is the number denoted by numeral X)

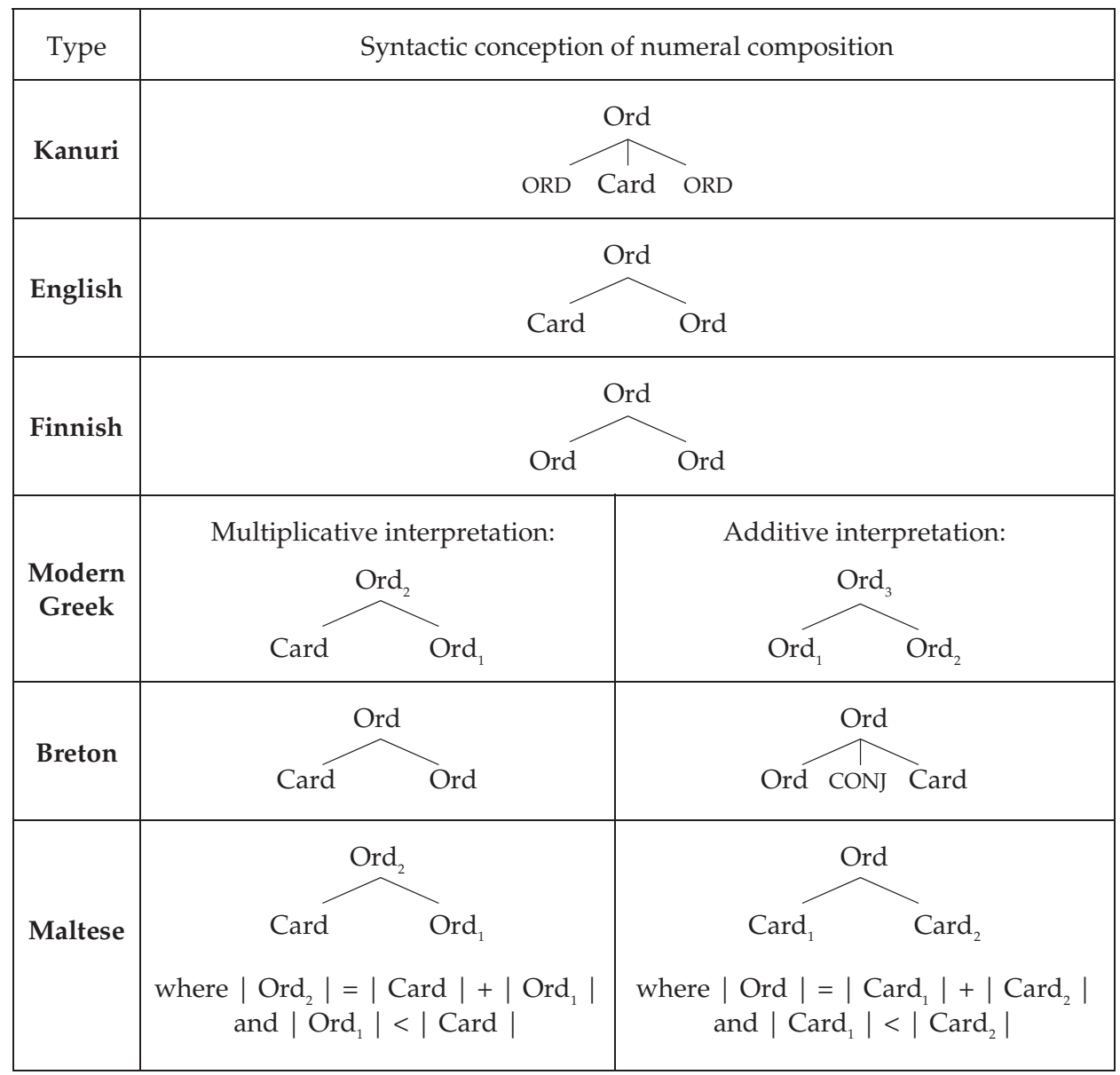

\subsection{Ambiguous ordinal marking: External or internal?}

In twenty-first, the incidence of suppletion in the ordinal marking of the numeral one makes it clear that the ordinal marking is, in these instances, internal. But in some languages, a single pattern of ordinal marking is exceptionlessly used for all numerals, including low numerals. In languages of this sort, ordinal marking may be ambiguous, being neither clearly external nor clearly internal. This ambiguity may arise with suffixal ordinal marking, as in (28), or prefixal marking, as in (29).
(28)
20-1-ORD:
[20-1]-ORD
or 20-[1-ORD]
(29) ORD-20-1:
ORD-[20-1]
or [ORD-20]-1 ? 
The Uyghur evidence in (30) exemplifies the ambiguous suffixal type (28), which is either external or internal, right-peripheral; the Tagalog evidence in (31) exemplifies the ambiguous prefixal type (29), which is either external or internal, left-peripheral.

(30) Uyghur [Altaic, Turkic] exhibits ordinal marking of the AMBIGUOUS SUFFIXAL type

\begin{tabular}{|l|l|ll|ll|}
\hline Cardinal: & bir ' 1 ' & yigirmä '20' & yigirmä bir & '21' \\
& 1 & 20 & 20 & 1 \\
\hline Ordinal: & bir-inči '1st' & yigirm-inči '20th' & yigirmä bir-inči '21st' \\
& 1-ORD & 20-ORD & 20 & 1-ORD \\
\hline
\end{tabular}

\begin{tabular}{|c|c|c|}
\hline Bhojpuri & [IE; Indic] & Shukla 1981: 88. \\
\hline Kwaami & [Afro-Asiatic; Chadic] & $\begin{array}{l}\text { Leger 1994: 188-92. The form kúmó kán } \\
\text { múndînkì '11th' confirmed by Rudolf } \\
\text { Leger (p. c., June 2008). }\end{array}$ \\
\hline K'abeena & [Afro-Asiatic; Cushitic] & Crass 2005: 207-18. \\
\hline Amharic & [Afro-Asiatic; Semitic] & Leslau 1995: 251-65. \\
\hline Turkish & [Altaic; Turkic] & Lewis 1967: 79-83. \\
\hline Japanese & [Japanese] & Akiyama \& Akiyama 1991: 172-74. \\
\hline Beria & [Nilo-Saharan; Saharan] & Jakobi \& Crass 2004. \\
\hline Hunzib & [N. Caucasian; Daghestanian] & van den Berg 1995: 68-70. \\
\hline
\end{tabular}

(31) In Tagalog [Austronesian, Malayo-Polynesian], ordinal marking is of the AMBIGUOUS PREFIXAL type:

\begin{tabular}{|c|c|c|c|c|c|}
\hline Cardinal: & isá ' 1 ' & dalawampúp & ‘20’ & dalawampú-t-isá & '21' \\
\hline Ordinal: & ika-isá '1st' & ika-dalawampú? & ‘20th’ & ika-dalawampú-t-isá & ‘21st’ \\
\hline \multicolumn{6}{|c|}{ Source: Llamzon 1976: 117f. } \\
\hline \multicolumn{6}{|c|}{ Additional languages of this type: } \\
\hline Malay & \multirow{4}{*}{\multicolumn{2}{|c|}{$\begin{array}{l}\text { [Austronesian; Malayo-Polynesian] } \\
\text { [Austronesian; Malayo-Polynesian] } \\
\text { [Austronesian; Malayo-Polynesian] } \\
\text { [Austronesian; Paiwan] }\end{array}$}} & \multirow{4}{*}{\multicolumn{3}{|c|}{$\begin{array}{l}\text { Dodds 1977: 34, 65-66. } \\
\text { Benton 1971: 144-54. } \\
\text { Du Feu 1996: 170-73. } \\
\text { Egli 1990: 149-53. }\end{array}$}} \\
\hline Pangasina & & & & & \\
\hline Rapanui & & & & & \\
\hline Paiwan & & & & & \\
\hline
\end{tabular}


Moreover, the possibility of conjunct ordinal morphology brings even more languages into these ambiguous categories. Consider, for instance, the French evidence in (32). On first consideration, the fact that vingt et un 'twenty-one' has vingt-et-unieme rather than *vingt-premier as its ordinal suggests that French ordinal marking is external, in direct contrast to the internal, right-peripheral marking of English tmenty-first. But if premier/unième are regarded as an absolute/conjunct pair comparable to Breton kentañ/unanved or Finnish ensimmäinen/yhdes or Modern Georgian p'irveli/me-ert-e, then vingt-et-unième can instead be seen as involving internal, right-peripheral marking. Similar facts hold true for ordinals in the other languages listed in (32). And analogously, the Berber evidence in (33) can be seen as involving either external ordinal marking or internal, left-peripheral ordinal marking.

(32) French [IE; Italic] exhibits ordinal marking of the AMBIGUOUS SUFFIXAL type (external marking or internal marking with SPECIAL CONJUNCT MORPHOLOGY)

\begin{tabular}{|c|c|c|c|c|}
\hline Cardinal: & un (m.) ' 1 ' & $\begin{array}{l}\text { vingt } \\
20\end{array}$ & $' 20{ }^{\prime}$ & $\begin{array}{l}\text { vingt et un }(\mathrm{m} .) \quad ' 21^{\prime} \\
20 \quad \& 1\end{array}$ \\
\hline Ordinal: & $\begin{array}{l}\text { premier '1st' } \\
\text { 1.ORD }\end{array}$ & $\begin{array}{l}\text { vingtième } \\
\text { 20.ORD }\end{array}$ & '20th' & $\begin{array}{l}\text { vingt-et-unième '21st' } \\
\text { 20-\&-1.ORD }\end{array}$ \\
\hline \multicolumn{5}{|c|}{ Additional languages of this type: } \\
\hline Boraana Oromo & \multicolumn{2}{|c|}{ [Afro-Asiatic; Cushitic] } & \multicolumn{2}{|c|}{ Stroomer 1995: 58-61. } \\
\hline Evenki & \multicolumn{2}{|c|}{ [Altaic; Tungus] } & \multicolumn{2}{|c|}{ Nedjalkov 1997: 281-82. } \\
\hline Manchu & \multicolumn{2}{|l|}{ [Altaic; Tungus] } & \multicolumn{2}{|c|}{ Gorelova 2002: 200-04. } \\
\hline Udihe & \multicolumn{2}{|l|}{ [Altaic; Tungus] } & \multicolumn{2}{|c|}{ Nikolaeva \& Tolskaya 2001: 417-24. } \\
\hline Manam & \multicolumn{2}{|c|}{ [Austronesian; M.-P.] } & \multicolumn{2}{|c|}{ Lichtenberk 1983: 337-44. } \\
\hline Albanian & \multicolumn{2}{|l|}{ [IE; Albanian] } & \multicolumn{2}{|c|}{ Buchholz \& Fiedler 1987: 349-57. } \\
\hline Western Armenian & \multicolumn{2}{|l|}{ [IE; Armenian] } & \multicolumn{2}{|c|}{ Sakayan 2000: 119-21. } \\
\hline Hindi & \multicolumn{2}{|l|}{ [IE; Indic] } & \multicolumn{2}{|c|}{ McGregor 1995: 67-70. } \\
\hline Sanskrit & \multicolumn{2}{|l|}{ [IE; Indic] } & \multicolumn{2}{|c|}{ Cardona 2007: 801-2; Whitney 1889: 177-85. } \\
\hline Persian & \multicolumn{2}{|l|}{ [IE; Iranian] } & \multicolumn{2}{|c|}{ Boyle 1966: 28-29; Perry 2007: 990-92. } \\
\hline Italian & \multicolumn{2}{|l|}{ [IE; Italic] } & \multicolumn{2}{|c|}{ Proudfoot \& Cardo 1997: 112-18. } \\
\hline Romanian & \multicolumn{2}{|l|}{ [IE; Italic] } & \multicolumn{2}{|c|}{$\begin{array}{l}\text { Daniliuc \& Daniliuc 2000: 121-30; Gönczöl- } \\
\text { Davies 2007: 78-82. }\end{array}$} \\
\hline Basque & \multicolumn{2}{|l|}{ [Isolate] } & \multicolumn{2}{|c|}{ Hualde \& Ortiz de Urbina 2003: 126-29. } \\
\hline Korean & \multicolumn{2}{|l|}{ [Isolate] } & \multicolumn{2}{|c|}{ Martin 1992: 174-79. } \\
\hline Chol & \multicolumn{2}{|l|}{ [Mayan] } & \multicolumn{2}{|c|}{ Warkentin \& Scott 1980: 107-10. } \\
\hline Bezhta & \multicolumn{2}{|c|}{ [N. Caucasian; Daghestanian] } & \multicolumn{2}{|c|}{ Kibrik \& Testelets 2004: 274-77. } \\
\hline Adamawa Fulani & \multicolumn{2}{|c|}{ [Niger-Congo; Atlantic] } & Stenne & $967: 114-18$. \\
\hline Wolof & [Niger-Congo; & intic] & Ngom & $3: 45-49$ \\
\hline Koromfe & [Niger-Congo; & ta-Congo] & Rennis & 1997: 299-309. \\
\hline Supyire & [Niger-Congo; & ta-Congo] & Carlso & 994: 167-71. \\
\hline Koyra Chiini & [Nilo-Saharan; & ghai] & Heath & 9: $69-71,74-76$ \\
\hline Hungarian & [Uralic; Ugric] & & Round & $001: 241-43$. \\
\hline
\end{tabular}


(33) Berber [Afro-Asiatic] exhibits ordinal marking of the AMBIGUOUS PREFIXAL type (external marking or internal marking with SPECIAL CONJUNCT MORPHOLOGY)

\begin{tabular}{|l|lc|ll|ll|}
\hline Cardinal: & yan (m.) & '1’ & mraw (m.) & '10' & yan d mraw (m.) '11' \\
\hline Ordinal: & amezwaru & '1st' & wis mraw & '10th' & wis yan d mraw & '11th' \\
\hline Source: Quitout 1997: 75-86.
\end{tabular}

\section{Conclusions}

The evidence motivating the typology developed here demonstrates that the rules of composition involved in the derivation of ordinals from compound numerals are highly variable across languages; for this reason, the hypothesis that (1) is the sole rule of composition needed for a language's derivational morphology cannot be maintained.

(1) Rule of composition for $\operatorname{Deriv:} \operatorname{Deriv}([\mathrm{X} Y])=[\mathrm{X} \operatorname{Deriv}(\mathrm{Y})]$

The important theoretical conclusion highlighted by the ordinal evidence is that in formal terms, processes of derivation must be seen as having two components: rules of derivational exponence and rules of composition. Many derivational processes involve only a single, default rule of composition comparable to (1); and at least some derivational processes lack even this, insofar as they do not apply to compounds at all. But processes of ordinal derivation reveal a range of alternatives to the rule of composition in (1).

Ultimately, it is not surprising that ordinal derivation should exhibit such a diversity of rules of composition, since in most languages, compound numerals have a much greater type frequency among the bases of ordinal derivation than noncompound numerals. In English, for example, there are fewer than twenty monomorphemic numerals (e.g. zero, one, two, three, four, five, six, seven, eight, nine, ten, eleven, twelve, hundred, thousand, million and googol), all other numerals being compounds; thus, processes of ordinal derivation are different from most derivational processes in that, in terms of type frequency, they apply mainly to compounds. Moreover, the structure of cardinal numeral compounds varies widely across languages (as noted above in connection with the evidence in (8)); accordingly, it should come as no surprise that languages negotiate the formation of the corresponding ordinal compounds in a variety of ways.

\section{Notes}

1. Versions of this paper were presented at the University of Surrey (August 2009), at the conference on Universals and Typology in Word-Formation at P. J. Šfárik University, Košice, Slovakia (August 2009), and at the Linguistics Association of Great Britain Annual Meeting, University of Edinburgh (September 2009). Thanks to the audience members at all three 
events for a number of helpful comments; thanks, too, to two anonymous referees for their suggestions.

2. For discussion of the varied ways in which languages form ordinal derivatives from simple cardinal numerals, see Stolz \& Veselinova (2005).

\section{References}

Abu-Chacra, Faruk. 2007. Arabic: An essential grammar. London and New York: Routledge.

Akiyama, Nobuo, \& Carol Akiyama. 1991. Japanese grammar. Hauppauge, NY: Barron's Educational Series.

Ariste, Paul. 1968. A grammar of the Votic language. Bloomington: Indiana University and The Hague: Mouton \& Co.

Aronson, Howard I. 1989. Georgian: A reading grammar [corrected edition]. Columbus, $\mathrm{OH}$ : Slavica.

Aronson, Howard I. 1991. Modern Georgian. In Alice C. Harris (ed), The indigenous languages of the Caucasus, Volume 1: The Kartvelian languages. Delmar, NY: Caravan Books. 219-312.

Benton, Richard A. 1971. Pangasinan reference grammar. Honolulu: University of Hawaii Press.

Bielec, Dana. 1998. Polish: An essential grammar. London and New York: Routledge.

Borg, Albert \& Marie Azzopardi-Alexander. 1997. Maltese. London \& New York: Routledge.

Boyle, John Andrew. 1966. Grammar of Modern Persian. Wiesbaden: Harrassowitz.

Buchholz, Oda, \& Wilfried Fiedler. 1987. Albanische Grammatik. Leipzig: Verlag Enzyklopädie.

Butt, John, \& Carmen Benjamin. 1988. A nem reference grammar of Modern Spanish. London: Arnold.

Cardona, George. 2007. Sanskrit morphology. In Alan S. Kaye (ed), Morphologies of Asia and Africa, Vol. 2. Winona Lake, IN: Eisenbrauns. 775-824.

Carlson, Robert. 1994. A grammar of Supyire. Berlin and New York: Mouton de Gruyter.

Catalán, Norma. 1995. Evaluative affixation and lexical compounding in Spanish: an account within Optimality Theory. Paper presented at the $48^{\text {th }}$ Kentucky Foreign Language Conference, University of Kentucky, Lexington, Kentucky.

Crass, Joachim. 2005. Das K’abeena. Köln: Köppe.

Cyffer, Norbert. 2007. Kanuri morphology. In Alan S. Kaye (ed), Morphologies of Asia and Africa, Vol. 2. Winona Lake, IN: Eisenbrauns. 1089-1126.

Daniliuc, Laura, \& Radu Daniliuc. 2000. Descriptive Romanian grammar. Munich: Lincom Europa.

Dayley, Jon P. 1989. Tümpisa (Panamint) Shoshone grammar. Berkeley, Los Angeles and Oxford: University of California Press.

Décsy, Gyula. 1966. Yurak chrestomathy. Bloomington: Indiana University and The Hague: Mouton.

Dodds, R. W. 1977. Malay. London: Hodder \& Stoughton.

Donaldson, Bruce C. 1993. A grammar of Afrikaans. Berlin and New York: Mouton de Gruyter.

Du Feu, Veronica. 1996. Rapanui. London and New York: Routledge.

Egli, Hans. 1990. Paimangrammatik. Wiesbaden: Otto Harrassowitz.

Everett, Daniel L. \& Barbara Kern. 1997. Wari'. London and New York: Routledge.

Fähnrich, Heinz. 1987. Kurze Grammatik der georgischen Sprache. Leipzig: Verlag Enzyklopädie.

Fähnrich, Heinz. 1991. Old Georgian. In Alice C. Harris (ed), The indigenous languages of the Caucasus, Volume 1: The Kartvelian languages. Delmar, NY: Caravan Books. 129-217.

Fehringer, Carol. 1999. A reference grammar of Dutch. Cambridge: Cambridge University Press. 
Fennell, Trevor G. \& Henry Gelsen. 1980. A grammar of Modern Latvian, vol. 1. The Hague: Mouton.

Fortescue, Michael. 1984. West Greenlandic. London: Croom Helm.

Gönczöl-Davies, Ramona. 2007. Romanian: An essential grammar. London and New York: Routledge.

Gordon, E. V. 1957. An introduction to Old Norse [2 ${ }^{\text {nd }}$ edition, revised by A. R. Taylor]. Oxford: Oxford University Press.

Gorelova, Liliya M. 2002. Manchu grammar. Leiden, Boston and Köln: Brill.

Hahn, Reinhard F. 1991. Spoken Uyghur. Seattle \& London: University of Washington Press.

Hahn, Revd. Ferd. 1985. Grammar of the Kurukh language. Delhi: Mittal Publications.

Hammond, Lila. 2005. Serbian: An essential grammar. London and New York: Routledge.

Hammond, R. 1981. A German reference grammar. Oxford: Oxford University Press.

Heath, Jeffrey. 1999. A grammar of Koyra Chiini: The Songhay of Timbuktu. Berlin and New York: Mouton de Gruyter.

Herrity, Peter. 2000. Slovene: A comprehensive grammar. London and New York: Routledge.

Holmes, Philip, \& Ian Hinchliffe. 2003. Smedish: A comprehensive grammar [2 $2^{\text {nd }}$ edition]. London and New York: Routledge.

Hualde, José Ignacio, \& Jon Ortiz de Urbina (eds.) 2003. A grammar of Basque. Berlin and New York: Mouton de Gruyter.

Hurford, J. R. 1975. The linguistic study of numerals. Cambridge: Cambridge University Press.

Hutchison, John P. 1981. A reference grammar of the Kanuri language. Madison: African Studies Program, University of Wisconsin and Boston: African Studies Center, Boston University.

Jakobi, Angelika, \& Joachim Crass. 2004. Grammaire du beria (langue saharienne). Köln: Köppe. Janaš, Pětr. 1976. Niedersorbische Grammatik. Bautzen: VEB Domowina-Verlag.

Joseph, Brian D. \& Irene Philippaki-Warburton. 1987. Modern Greek. London: Croom Helm.

Josephs, Lewis S. 1975. Palauan reference grammar. Honolulu: University Press of Hawaii.

Karlsson, Fred. 1999. Finnish: An essential grammar. London and New York: Routledge.

Karttunen, Lauri. 2006. Numbers and Finnish numerals. In Mickael Suominen, Antti Arppe, Anu Airola, Orvokki Heinämäki, Matti Miestamo, Urho Määttä, Jussi Niemi, Kari K. Pitkänen and Kaius Sinnemäki (eds), A man of measure: Festschrift in honour of Fred Karlsson on his 60th birthday [supplement to SKY Journal of Linguistics, vol. 19], 407-421.

Kervella, F. 1976. Yezhadur bras ar brezhoneg. Brest: Al Liamm.

Kibrik, A. E. \& Ja. G. Testelets. 2004. Bezhta. In Michael Job (ed), The indigenous languages of the Caucasus, Volume 3: The North East Caucasian languages, Part 1. Ann Arbor: Caravan Books. 217-295.

King, Gareth. 1993. Modern Welsh: A comprehensive grammar. London and New York: Routledge. LaPolla, Randy J. with Chenglong Huang. 2003. A grammar of Qiang with annotated texts and glossary. Berlin and New York: Mouton de Gruyter.

Leslau, Wolf. 1995. Reference grammar of Amharic. Wiesbaden: Harrassowitz.

Lewis, G. L. 1967. Turkish grammar. Oxford: Oxford University Press.

Lichtenberk, Frantisek. 1983. A grammar of Manam. Honolulu: University of Hawaii Press.

Llamzon, Teodoro A. 1976. Modern Tagalog: A functional-structural description. The Hague and Paris: Mouton.

Lorentz, F. 1971. Kaschubische Grammatik. Hildesheim: Gerstenberg.

McGregor, R. S. 1995. Outline of Hindi grammar. Oxford: Oxford University Press.

Naughton, James. 2005. Czech: An essential grammar. London and New York: Routledge.

Nedjalkov, Igor. Evenki. London and New York: Routledge. 
Ngom, Fallou. 2003. Wolof. Munich: Lincom Europa.

Nikolaeva, Irina, \& Maria Tolskaya. 2001. A grammar of Udihe. Berlin and New York: Mouton de Gruyter.

Olawsky, Knut J. 2006. A grammar of Urarina. Berlin and New York: Mouton de Gruyter.

Perini, Mário A. 2002. Modern Portuguese: A reference grammar. New Haven and London: Yale University Press.

Perry, John R. 2007. Persian morphology. In Alan S. Kaye (ed), Morphologies of Asia and Africa, Vol. 2. Winona Lake, IN: Eisenbrauns. 975-1019.

Proudfoot, Anna \& Francesco Cardo. 1997. Modern Italian grammar. London and New York: Routledge.

Pugh, Stefan M. \& Ian Press. 1999. Ukrainian: A comprehensive grammar. London and New York: Routledge.

Quitout, Michel. 1997. Grammaire berbère. Montreal: L'Harmattan.

Rå Hauge, Kjetil. 1999. A short grammar of contemporary Bulgarian. Bloomington, IN: Slavica.

Reh, Mechthild. 1996. Anyma language: Description and internal reconstructions. Köln: Köppe.

Rounds, Carol. 2001. Hungarian: An essential grammar. London and New York: Routledge.

Ryding, Karin C. 2005. A reference grammar of Modern Standard Arabic. Cambridge: Cambridge University Press.

Sakayan, Dora. 2000. Modern Western Armenian. Montreal: Arod Books.

Schaub, Willi. 1985. Babungo. London: Croom Helm.

Senn, Alfred. 1966. Handbuch der litauischen Sprache (Band I: Grammatik). Heidelberg: Winter.

Shukla, Shaligram. 1981. Bhojpuri grammar. Washington, DC: Georgetown University Press.

Spencer, Andrew. 1988. Bracketing paradoxes and the English lexicon. Language 64: 663-682.

Stampe, David. 1976. Cardinal number systems. In S. Mufwene, C. Walker, \& S. Steever, eds., Papers from the Twelfth Regional Meeting of the Chicago Linguistic Society, 594-609. Chicago: Chicago Linguistic Society.

Stennes, Leslie H. 1967. A reference grammar of Adamama Fulani. East Lansing: African Studies Center, Michigan State University.

Stolz, Thomas \& Lyuba N. Veselinova. 2005. Ordinal numerals. In Martin Haspelmath, Matthew S. Dryer, David Gil \& Bernard Comrie, eds., The morld atlas of language structures. Oxford: Oxford University Press. 218-221.

Strandskogen, Åse-Berit, \& Rolf Strandskogen. 1986. Normegian: An essential grammar [tr. by Barbara White]. London \& New York: Routledge.

Stroomer, Harry. 1995. A grammar of Boraana Oromo (Kenya). Köln: Köppe.

Stump, Gregory T. 1995. The uniformity of head marking in inflectional morphology. Yearbook of Morphology 1994: 245-296.

Stump, Gregory T. 2001. Inflectional morphology. Cambridge: Cambridge University Press.

Sulkala, Helena, \& Merja Karjalainen. 1992. Finnish. London and New York: Routledge.

Terrill, Angela. 2003. A Grammar of Lavukaleve. Berlin \& New York: Mouton de Gruyter.

Trépos, Pierre 1968. Grammaire bretonne [1980 reprint]. Rennes: Ouest France.

van den Berg, Helma. 1995. A grammar of Hunzib (mith texts and lexicon). Munich and Newcastle: Lincom Europa.

van Driem, George. 1987. A grammar of Limbu. Berlin, New York and Amsterdam: Mouton de Gruyter.

van Driem, George. 1993. A grammar of Dumi. Berlin \& New York: Mouton de Gruyter.

Wade, Terence. 1992. A comprehensive Russian grammar. Oxford and Cambridge, MA: Blackwell.

Warkentin, Viola, \& Ruby Scott. 1980. Gramática Ch'ol. Mexico: Instituto Lingüístico de Verano. 
Werner, Roland. 1987. Grammatik des Nobiin (Nilnubisch). Hamburg: Helmut Buske Verlag. Wheelock, Frederic M. 1963. Latin: An introductory course based on ancient authors [ ${ }^{\text {rd }}$ edition].

New York, Evanston, San Francisco and London: Barnes \& Noble.

Whitney, W. D. 1889. Sanskrit grammar [2nd edition]. Cambridge, MA: Harvard University Press. Williams, Stephen J. 1980. A Welsh grammar. Cardiff: University of Wales Press.

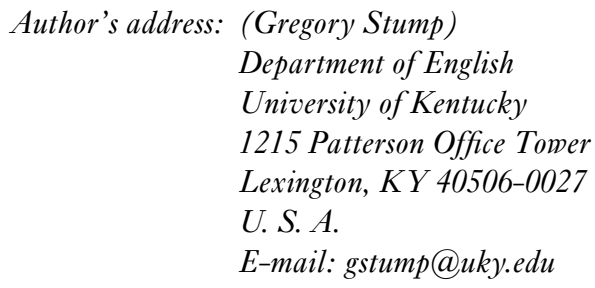

